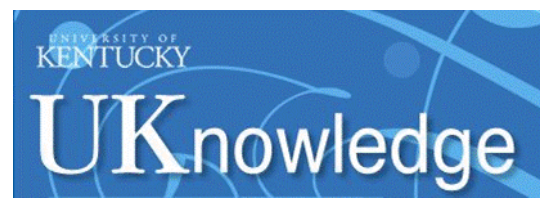

University of Kentucky

UKnowledge

Microbiology, Immunology, and Molecular Genetics Faculty Publications

Microbiology, Immunology, and Molecular Genetics

2-2017

\title{
Pneumocystis Infection Alters the Activation State of Pulmonary Macrophages
}

Jessica M. Deckman

University of Kentucky

Cathryn J. Kurkjian

University of Kentucky

Joseph P. McGillis

University of Kentucky, joseph.mcgillis@uky.edu

Theodore J. Cory

University of Kentucky, theodorecory@gmail.com

Susan E. Birket

University of Kentucky, susan.birket@uky.edu

Follow this and additional works at: https://uknowledge.uky.edu/microbio_facpub

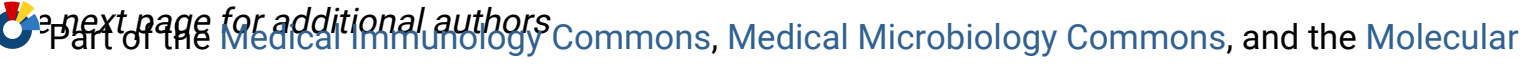
Genetics Commons

Right click to open a feedback form in a new tab to let us know how this document benefits you.

\section{Repository Citation}

Deckman, Jessica M.; Kurkjian, Cathryn J.; McGillis, Joseph P.; Cory, Theodore J.; Birket, Susan E.;

Schutzman, Linda M.; Murphy, Brian S.; Garvy, Beth A.; and Feola, David J., "Pneumocystis Infection Alters the Activation State of Pulmonary Macrophages" (2017). Microbiology, Immunology, and Molecular Genetics Faculty Publications. 137.

https://uknowledge.uky.edu/microbio_facpub/137

This Article is brought to you for free and open access by the Microbiology, Immunology, and Molecular Genetics at UKnowledge. It has been accepted for inclusion in Microbiology, Immunology, and Molecular Genetics Faculty Publications by an authorized administrator of UKnowledge. For more information, please contact UKnowledge@lsv.uky.edu. 
Pneumocystis Infection Alters the Activation State of Pulmonary Macrophages

Digital Object Identifier (DOI)

https://doi.org/10.1016/j.imbio.2016.10.003

Notes/Citation Information

Published in Immunobiology, v. 222, issue 2, p. 188-197.

(c) 2016 Elsevier GmbH. All rights reserved.

This manuscript version is made available under the CC-BY-NC-ND 4.0 license

https://creativecommons.org/licenses/by-nc-nd/4.0/.

The document available for download is the author's post-peer-review final draft of the article.

Authors

Jessica M. Deckman, Cathryn J. Kurkjian, Joseph P. McGillis, Theodore J. Cory, Susan E. Birket, Linda M. Schutzman, Brian S. Murphy, Beth A. Garvy, and David J. Feola

This article is available at UKnowledge: https://uknowledge.uky.edu/microbio_facpub/137 
Published in final edited form as:

Immunobiology. 2017 February ; 222(2): 188-197. doi:10.1016/j.imbio.2016.10.003.

\title{
Pneumocystis Infection Alters the Activation State of Pulmonary Macrophages
}

\author{
Jessica M. Deckman ${ }^{a}$, Cathryn J. Kurkjian ${ }^{a}$, Joseph P. McGillis ${ }^{a}$, Theodore J. Cory ${ }^{b}$, Susan \\ E. Birket ${ }^{\mathrm{b}}$, Linda M. Schutzman ${ }^{\mathrm{c}}$, Brian S. Murphyc, Beth A. Garvy ${ }^{\mathrm{a}}$, and David J. Feolab, \\ aDepartment of Microbiology, Immunology, and Molecular Genetics, University of Kentucky \\ College of Medicine, 800 Rose Street Rm MS409, Lexington, Kentucky 40536, USA \\ bDepartment of Pharmacy Practice and Science, University of Kentucky College of Pharmacy, \\ 789 S. Limestone Street Suite 292, Lexington, Kentucky 40536, USA
}

'Department of Internal Medicine, University of Kentucky College of Medicine, $900 \mathrm{~S}$. Limestone Street Suite 303, Lexington, Kentucky 40536, USA

\begin{abstract}
Recent studies show a substantial incidence of Pneumocystis jirovecii colonization and infection in patients with chronic inflammatory lung conditions. However, little is known about the impact of Pneumocystis upon the regulation of pulmonary immunity. We demonstrate here that Pneumocystis polarizes macrophages towards an alternatively activated macrophage-like phenotype. Genetically engineered mice that lack the ability to signal through IL-4 and IL-13 were used to show that Pneumocystis alternative macrophage activation is dependent upon signaling through these cytokines. To determine whether Pneumocystis-induced macrophage polarization would impact subsequent immune responses, we infected mice with Pneumocystis and then challenged them with Pseudomonas aeruginosa 14 days later. In co-infected animals, a higher proportion of macrophages in the alveolar and interstitial spaces expressed both classical and alternatively activated markers and produced the regulatory cytokines TGF $\beta$ and IL-10, as well as higher arginase levels than in mice infected with $P$. aeruginosa alone. Our results suggest that Pneumocystis reprograms the overall macrophage repertoire in the lung to that of a more alternatively-activated setpoint, thereby altering subsequent immune responses. These data may help to explain the association between Pneumocystis infection and decline in pulmonary function.
\end{abstract}

\section{Keywords}

macrophage; Pneumocystis; inflammation; arginase

\footnotetext{
*Corresponding author at the University of Kentucky College of Pharmacy, 789 S. Limestone Street Rm 231, Lexington, KY 40536, USA.djfeol2@email.uky.edu.

Publisher's Disclaimer: This is a PDF file of an unedited manuscript that has been accepted for publication. As a service to our customers we are providing this early version of the manuscript. The manuscript will undergo copyediting, typesetting, and review of the resulting proof before it is published in its final citable form. Please note that during the production process errors may be discovered which could affect the content, and all legal disclaimers that apply to the journal pertain.

Conflict of Interest

The authors declare that they have no conflicts of interest.
} 


\section{Introduction}

Pneumocystis jiroveci is an opportunistic fungal pathogen that often causes pneumonia in immunocompromised patients. Recently it was recognized that colonization with Pneumocystis is associated with a decline in pulmonary function in smokers and patients with severe forms of chronic obstructive pulmonary disease (COPD) (Morris et al., 2000; Morris et al., 2004b; Morris et al., 2008a) as well as cystic fibrosis (CF) (Calderon et al., 2010; Friaza et al., 2010; Sing et al., 2001). In addition to colonization and infection with multiple microorganisms, these patients have the hallmarks of chronic lung diseases (airway inflammation, airway remodeling, and parenchymal damage). This creates a complex microenvironment that complicates our understanding of the role of microbes during the development of pulmonary damage and repair. It is unknown whether the presence of Pneumocystis alters the homeostatic set point of immune activation, nor how this influences subsequent pulmonary insults.

Macrophages play a key role in the clearance of Pneumocystis infection (Ezekowitz et al., 1991; Limper et al., 1997; Masur et al., 1978; O'Riordan et al., 1995). They account for the majority of inflammatory cells recovered in bronchoalveolar lavage (BAL) samples from COPD patients and are localized to sites of alveolar destruction. The influence of specific macrophage characteristics on other immune cell types during pulmonary infection with Pneumocystis are poorly understood. Macrophages have been described along a continuum of gene expression patterns and functional status (Mantovani et al., 2002; Montaner et al., 1999; Nelms et al., 1999; Stout et al., 2004). In contrast to the classical activation of macrophages (CAM) induced by Th1 cytokines to an inflammatory effector cell that utilizes reactive oxygen species for pathogen elimination (Mantovani et al., 2002; Munder et al., 1998), alternatively-activated macrophages (AAM) not only orchestrate inflammation during Th2-type responses, but also play a role in the regulation of inflammation and the coordination of extracellular matrix protein production responsible for tissue remodeling and repair (Gordon, 2003). AAMs demonstrate marked up-regulation of mannose receptor (MR), $\mathrm{CD} 23$, and arginase 1, the latter of which is thought to be responsible for inhibition of CAM responses in mice (Bansal et al., 2003; El Kasmi et al., 2008; Herbert et al., 2004; Herbert et al., 2010). The role of alternative macrophage activation during Pneumocystis infection and colonization is unknown and represents an opportunity to better understand the role of Pneumocystis colonization in patients with chronic lung diseases.

Evidence suggests that alternative macrophage activation plays a role in the pathogenesis of COPD and CF and could have significant implications in the evolution of inflammation and pulmonary remodeling in this setting (El Kasmi et al., 2008; Pesce et al., 2009a; Pesce et al., 2009b; Wilson et al., 2009; Wynn et al., 2010). Our previous work found that immune responses to acute bacterial pneumonia can be altered by manipulating alternative macrophage activation. Induction of an AAM-like phenotype in a mouse model of Pseudomonas pulmonary infection causes a blunted neutrophil influx and decreased peribronchiolar inflammation (Feola et al., 2010). The induction of arginase 1 expression in these mice infected with Pseudomonas, as well as in other models of infection including Schistosoma mansoni, appears to be protective through the suppression of excessive inflammation (Feola et al., 2010; Pesce et al., 2009a). Although much is known of the 
function of arginase in the coordination of remodeling and repair, several studies have also investigated its role in the inflammatory response to pathogens that elicit both Th1- and Th2type responses. With Th1-dominant infections, $\operatorname{Arg} 1$ expression counters effective responses by suppressing NO production, as shown in mouse models of Mycobacterium species and Toxoplasoma gondii infection (El Kasmi et al., 2008). Conversely however, in the Th2dominant response to Schistosoma mansoni, macrophage-specific expression of arginase-1 regulates the pathologic aspects of Th2-driven inflammation and fibrosis (Herbert et al., 2004; Pesce et al., 2009b).

Here, we demonstrate that Pneumocystis infection induces characteristics of alternative macrophage activation both in vitro and in vivo. We also show that the Pneumocystisinduced AAM phenotype persists and alters the immune response to a secondary bacterial challenge. Additional studies in IL-4Ra ${ }^{-/-}$mice suggest that Pneumocystis-mediated macrophage polarization is, to an extent, dependent upon IL-4 and/or IL-13 signaling, although this absence does not alter the kinetics of Pneumocystis clearance in these mice. These studies provide evidence for immune modulation as a result of colonization or infection with Pneumocystis that may influence the progression of pathology associated with chronic lung diseases.

\section{Materials and Methods}

\subsection{Mice}

Five- to 8-wk-old C57BL/6, BALB/c, and BALB/c-Il4ra ${ }^{\mathrm{tCAMSz} / \mathrm{J}}\left(\mathrm{IL}-4 \mathrm{Ra}^{-/-}\right)$mice were obtained from Jackson Laboratories, bred, and maintained at the AALAC accredited University of Kentucky Animal Facility. The IL- $4 \mathrm{Ra}^{-/-}$mouse is homozygous for the II4rat ${ }^{t C A M S Z}$ targeted mutation. IL-4Ra is a common chain that is present in IL-4 and IL-13 receptors and is required for transmitting signals for both cytokines (Kondo et al., 1993; Russell et al., 1993). These mice are unable to respond to IL-4/IL-13 to induce alternative macrophage activation. Mice were housed in pathogen-free isolation, given food and water ad libitum, and transferred to a biosafety housing unit after infection. Pneumocystis was maintained in a colony of $\mathrm{Rag} 1^{-/}$mice as a source for all infections. All experimental animal studies were approved by the University of Kentucky Institutional Animal Care and Use Committee and were conducted in accordance with the National Institutes of Health Guide for the Care and Use of Laboratory Animals.

\subsection{Enumeration of inoculated Pneumocystis organisms}

To prepare Pneumocystis for inoculation, lungs removed from infected Rag $1^{-/-}$mice were pushed through a stainless steel mesh and collected in HBSS. Debris was removed by centrifugation, and aliquots of lung homogenates were spun onto glass slides, fixed with methanol, stained using DiffQuik (Siemens, Germany) reagents, and the number of Pneumocystis nuclei were counted. To infect mice, animals were anesthetized lightly with isoflurane gas, and $10^{5}$ to $10^{7}$ Pneumocystis nuclei, depending upon the experiment, were

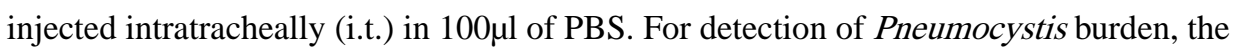
right lung lobes of each animal were excised, minced, and digested in RPMI 1640 supplemented with $2 \%$ fetal calf serum, $1 \mathrm{mg} / \mathrm{ml}$ collagenase A, and $50 \mathrm{U} / \mathrm{ml}$ DNase. 
Digested fractions were pushed through mesh screens, and aliquots were spun onto glass slides and stained with Diff-Quik for microscopic enumeration. Lung burden is expressed as $\log _{10}$ Pneumocystis nuclei per animal with a lower limit of detection of $\log _{10} 3.23$.

\subsection{Infection with $P$. aeruginosa}

The clinical mucoid strain P. aeruginosa M57-15, a gift from Anna Van Heeckeren, PhD, Case Western University, was used in these experiments. The bacteria were grown in trypticase soy broth (TSB) to late log phase or early stationary phase. The method for incorporation of the bacteria into agarose beads, essential to induce prolonged infection in mice, was adapted from previously described methods (Nacucchio et al., 1984; van Heeckeren et al., 2002). P. aeruginosa-laden agarose beads were diluted to achieve an

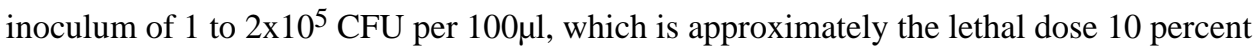
(LD10). Fourteen days after Pneumocystis inoculation as described above, $P$. aeruginosaladen beads were instilled intratracheally using a blunted 24-gauge curved inoculation needle while the animals were under isofluorane anesthesia. To confirm the actual inocula given, an aliquot of the bead preparation was homogenized and plated on Pseudomonas selection agar immediately after infection and counted after overnight incubation.

Mice were humanely euthanized on day 0 prior to infection with $P$. aeruginosa and on postinfection days 3 and 10. Bronchial alveolar lavage and lung digest samples were obtained as described above. An aliquot was plated to assess bacterial burden by manual CFU counting on Pseudomonas selection agar. This agar was used to avoid contamination from upper airway flora. We have verified that the lavage procedure does not significantly affect bacterial counts of homogenized lung tissue.

\subsection{Isolation of macrophages from alveolar space and lung interstitium}

Mice were humanely euthanized by exsanguination under deep anesthesia. The lungs were lavaged with $1 \mathrm{ml}$ aliquots of HBSS containing 3mM EDTA. Lungs were then removed and digested in medium as discussed above. After removing an aliquot for enumeration of Pneumocystis organisms, lung fragments were then filtered and red blood cells lysed in a hypotonic solution and analyzed as lung interstitium. Single cell suspensions of lavaged cells and lung digest were washed and counted.

\subsection{In vitro experiments}

Both an immortalized macrophage cell line and primary macrophages were utilized. Primary bone marrow and alveolar macrophages were harvested from naïve BALB/c and IL-4Ra ${ }^{-1-}$ mice. To obtain alveolar macrophages, lungs were lavaged as described above. Primary bone marrow macrophages were harvested after isolation of femurs and tibias by inserting a 26 gauge needle into the marrow and flushing with RPMI containing 5\% FBS and penicillin/ streptomycin. The J774A.1 cell line, an immortalized macrophage cell line obtained from adult BALB/c mice, was purchased from ATCC (Manassas, VA) (Ralph et al., 1975). The macrophages were plated in 24-well plates at $2 \times 10^{5}$ cells/well in RPMI (Invitrogen) supplemented with 5\% FBS, $\beta$-mercaptoethanol $(500 \mu \mathrm{M})$, and penicillin/streptomycin $(10000 \mathrm{Units} / \mathrm{ml}, 10000 \mu \mathrm{g} / \mathrm{ml})$. Cells were stimulated with IL-4 and IL-13 $(10 \mathrm{ng} / \mathrm{ml})$ plus LPS (50ng/ml), LPS alone, Pneumocystis organisms at a multiplicity of infection (MOI) of 
10 , or media alone. At $4 \mathrm{~h}$ and $24 \mathrm{~h}$ post-stimulation timepoints, cells were washed, harvested, and counted. Separate aliquots of cells were either stained for flow cytometry or preserved for protein or mRNA analyses.

\subsection{Flow cytometric analysis of immune cell populations}

Lung lavage and lung digest cells were washed in PBS containing 0.1\% BSA and $0.02 \%$ sodium azide and stained with appropriate concentrations of fluorochrome-conjugated antibodies specific for murine CD11b, CD11c, Gr-1/Ly6G, MR, CD23, FIZZ-1, or CCR7. Antibodies were purchased from eBioscience (San Diego, CA) or BD Biosciences (San Jose, CA). Surface expression was determined by multiparameter flow cytometry using a FACSCalibur cytofluorimeter (BD Biosciences). For intracellular cytokine staining, $2 \times 10^{6}$ cells from each sample were incubated for 4 hours with 50ng/ml PMA and 500ng/ml ionomycin, and in the presence of $10 \mu \mathrm{g} / \mathrm{ml}$ brefeldin A for the final 2 hours. Cells were surface stained for CD11b, CD11c, and GR-1 and fixed in $4 \%$ formalin. Subsequently, cells were permeabilized in $0.05 \%$ saponin, exposed to anti-CD16/32 antibody to block Fc binding, and incubated with fluorescently labeled antibodies specific for tumor necrosis factor (TNF)- $a$, transforming growth factor (TGF)- $\beta$, and interleukin (IL)-10. Cells were washed thoroughly and resuspended in PBS for analysis. Fluorescence characteristics for at least 50,000 events per sample were acquired using a BD LSRII Flow Cytometer System (BD Biosciences) and analyzed with FlowJo (version 7.5.5, Treestar, Ashland, Oregon). All analyses included isotype and single color controls.

\section{7. qRT-PCR of AAM gene expression}

For Arg1, Fizz1, and $Y m 1 \mathrm{mRNA}$ analysis, lung digest cell suspensions were collected in $0.5 \mathrm{ml}$ Allprotect stabilization reagent (Qiagen, Valencia, CA), and stored at $-80^{\circ} \mathrm{C}$ until analysis. Cells were homogenized on ice, and total RNA was isolated using RNeasy kits (Qiagen). mRNA was quantified with an ND-1000 (NanoDrop Technologies, Wilmington, DE). Reverse transcriptase reactions were performed with 10ng of mRNA using Taqman Reverse Transcriptase kit from Applied Biosystems (Carlsbad, CA). Quantitative real-time PCR reactions were performed using 2ng cDNA loaded in 386-well plates using an epMotion 5070 Automated Pipetting System (Eppendorf, Hamburg, Germany). qRT-PCR reactions were run using TaqMan Gene Expression Assay primers (Mm00657889_m1 (YmI); Mm00475988_m1 (Arg1); Mm00445109_m1 (Fizz1) and TaqMan Rodent GAPDH Control Reagents) with ABI Taqman Universal PCR Master Mix on a 7500HT Fast RealTime PCR System (Applied Biosystems).

\subsection{Arginase quantification}

Lung digest cell preparation aliquots were pelleted and lysed with buffer containing $10 \mathrm{mM}$ Tris-HCl, 0.4\% (w/v) Triton-X-100, and Roche Mini-tablet Protease Inhibitor Cocktail (Mannheim, Germany). Total protein was quantified using the bicinchoninic acid colorimetric detection assay (Thermo Fisher Scientific) in cell lysates. The activity of intracellular arginase was determined from lung digest cell lysates using the QuantiChrom Arginase Assay Kit (BioAssay Systems, Haward, CA), which measures the conversion of arginine to urea by arginase. After total protein quantification, $20 \mu \mathrm{l}$ of each sample was incubated with arginine buffer at $37^{\circ} \mathrm{C}$ for 6 hours. The urea detection reagent containing 
anti-isonitrosopropiophenone was then added, and the optical density was read using a $490 \mathrm{~nm}$ filter. Readings were standardized to either total protein or cell number against the optical density of each sample's control.

\subsection{Statistical analysis}

Differences between experimental groups were determined using 1-way or 2-way analysis of variance (ANOVA) where appropriate. Bonferroni's post hoc test was used when performing all pair-wise comparisons, and Dunnett's post hoc test was used when comparing groups to a single control condition. Differences were considered statistically significant when $\mathrm{p}<0.05$. Analyses were performed using GraphPad Prism software package (GraphPad Software, Inc., La Jolla, CA).

\section{Results}

\subsection{Pneumocystis infection causes changes in murine macrophage characteristics}

In the absence of underlying immunosuppression, normal BALB/c mice mount an immune response against Pneumocystis, resulting in organism lung burdens that peak by day 8-12, with clearance observed by day 21 post-infection (Qureshi et al., 2003b). To determine the kinetics of macrophage polarization in these animals, normal BALB/c mice were infected intratracheally with $10^{7}$ Pneumocystis nuclei and followed for 28 days. Clearance kinetics similar to those reported earlier were observed here (Qureshi et al., 2003a; Qureshi et al., 2003b), with a peak of infection on day 11 and clearance by day 21 (Fig. 1A). After a transient decrease in arginase production on day 4 post-infection, we consistently observed an increase in the amount of arginase present in the lungs at day 11 post-infection, and these protein levels remained elevated through day 21 despite Pneumocystis clearance from the lungs to below the limit of detection by this timepoint (Fig. 1B). We then compared the expression of AAM and CAM surface markers on infiltrating monocytes/macrophage populations, designated as $\mathrm{CD} 11 \mathrm{~b}^{+} \mathrm{GR} 1^{-}$, isolated from bronchoalveolar lavage or lung digest samples by flow cytometry. For the AAM proteins MR and CD23, expression of each was increased by Pneumocystis infection in both the alveolar space (lavage) and interstitium (digest) (Fig. 2A and B). Expression of both proteins was significantly increased at day 28 post-infection on $\mathrm{CD} 11 \mathrm{~b}^{+} \mathrm{GR} 1^{-}$cells in the lung lavage, which was beyond the time at which the organisms were cleared. Expression of MR and CD23 on infiltrating macrophages in the lung digest samples peaked on days 22 and 11, respectively, and returned to baseline levels by day 28 post-infection. Expression of CCR7, used here as a marker of classical macrophage activation, peaked at day 4 in the lung lavage, and day 11 in the lung digest. Expression was back to baseline levels by day 22 post-infection in both lung compartments. Taken together, results presented in Fig. 1 and 2 indicate that the macrophages adopt characteristics of alternative activation, particularly in the alveolar space and at a time after Pneumocystis has been cleared from the lungs.

\subsection{Pneumocystis-mediated polarization towards an AAM phenotype is partially dependent upon IL-4Ra}

To gain insight into the signaling mechanisms responsible for Pneumocystis-mediated macrophage polarization, we utilized IL-4Ra ${ }^{-1-}$ mice, which lack the receptor to transduce 
IL-4 and IL-13 signaling. IL-4 and IL-13 are cytokines produced by T lymphocytes (among others) that polarize macrophages to an alternatively-activated phenotype (Gordon, 2003). Primary alveolar macrophages from IL-4 $\mathrm{Ra}^{-1-}$ and wildtype (WT) animals were stimulated with Pneumocystis in vitro and then characterized for arginase expression after 24 hours of incubation. While arginase activity increased in both WT and IL-4Ra ${ }^{-1-}$ macrophages exposed to Pneumocystis over baseline controls (Fig. 3A), macrophages from IL-4Ra ${ }^{-/}$ mice exhibited a more modest up-regulation of arginase production following Pneumocystis exposure compared to the WT and media controls. Arginase expression produced in the cells isolated from IL-4 $\mathrm{Ra}^{-/}$mice is possibly occurring through another mechanism, as arginase can be up-regulated through stimulation by other means, including IL-10 signaling (Bernard et al., 2000; Corraliza et al., 1995; Modolell et al., 1995). This suggests that this response is at least partially dependent upon IL-4Ra signaling.

To evaluate whether this response occurs in vivo, we infected WT BALB/c and IL-4Ra $\mathrm{Ra}^{-/}$ mice with $10^{7}$ Pneumocystis nuclei and examined macrophage characteristics at day 7 postinfection. Similar to previous observations, a robust increase in arginase concentration in lung digest preparations was shown in WT animals infected with Pneumocystis in comparison to uninfected controls (Fig. 4A). This increase in arginase production was attenuated in IL-4 $\mathrm{Ra}^{-/-}$mice, although the increase was still significant compared to the uninfected group. The arginase activity in infected WT animals was approximately 5 times greater than those in the infected knockout group $(\mathrm{p}<0.05)$. Similar observations were made using gene expression analysis of total lung digest cell preparations. WT mice infected with Pneumocystis had robust up-regulation of mRNA expression of Arg1, Fizz1, and $\mathrm{Ym} 1 \mathrm{in}$ comparison to uninfected controls, but these responses were absent in IL-4Ra ${ }^{-/}$mice (Fig. 4B). These results suggest that IL-4 and/or IL-13 signaling is necessary for Pneumocystismediated induction of AAM gene expression and arginase activity in vivo.

Next, we examined macrophage phenotype in more depth using flow cytometric analyses of AAM marker expression in order to evaluate both resident $\left(\mathrm{CD} 11 \mathrm{c}^{+}\right)$and infiltrating $\left(\mathrm{CD} 11 \mathrm{~b}^{+}\right)$subsets on day 7 post-Pneumocystis infection. $\mathrm{CD} 11 \mathrm{~b}^{+} \mathrm{Gr} 1^{-}$and $\mathrm{CD} 11 \mathrm{c}^{+} \mathrm{Gr} 1^{-}$ cells isolated from bronchoalveolar lavages and lung digests of Pneumocystis-infected animals demonstrated a consistent up-regulation of the AAM marker MR in comparison to uninfected controls (Fig. 4C). This held true in both the WT and IL-4Ra ${ }^{-/-}$strains, and in both the $\mathrm{CD}_{11} \mathrm{~b}^{+}$(infiltrating) and $\mathrm{CD} 11 \mathrm{c}^{+}$(resident) subsets. By day 7 post-infection, the number of $\mathrm{CD}_{1} 1 \mathrm{~b}^{+}$cells expressing the classical macrophage activation marker CCR7 were decreased by Pneumocystis infection in both the WT and knockout strains in the alveolar space, but no change was observed in the lung digests in either mouse strain. The numbers of $\mathrm{CD} 11 \mathrm{c}^{+} \mathrm{CCR} 7^{+}$cells in the lung lavage were low at this timepoint, and not significantly affected by the infection in either strain of mouse. In the lung digest, there was a significant increase in the number of CD11 $\mathrm{c}^{+}$cells expressing CCR7 in the knockout animals $(\mathrm{p}<0.05)$, due to low expression in the uninfected knockout animals.

Cells from infected animals also exhibited an increase in intracellular staining for IL-10 and TGF- $\beta$ (Fig. 4D). Overall there was a more robust increase in the number of cells producing IL-10 in the WT animals. The knockout animals, in general, lacked an increase in macrophage production of both IL-10 and TGF- $\beta$. Interestingly, the numbers of CD11b ${ }^{+}$and 
CD11 $\mathrm{c}^{+}$cells producing TNF- $\mathrm{a}$ were significantly higher in the infected WT animals than in the infected IL-4Ra ${ }^{-1-}$ mice ( $\mathrm{p}<0.05$ ). Importantly, the Pneumocystis burden in the lungs of infected WT and IL-4Ra ${ }^{-/}$mice in each experimental replicate did not differ, as each strain similarly cleared the fungal burden from the lungs by day 21 post-infection (Fig. 4E). Taken together, these data suggest that AAM induction by Pneumocystis is, in large part, dependent upon IL-4Ra signaling, however clearance of the organism is not dependent upon it. The AAM protein that is the exception to this in our model is MR. It may be that, due to the role of MR in responding to fungal pathogens such as Pneumocystis, its expression is regulated by other mechanisms during this response.

\subsection{Pneumocystis infection alters macrophage responses to subsequent bacterial pneumonia}

Our data suggests that Pneumocystis infection causes alterations to macrophage programming for a substantial time period. We next set out to determine whether these changes could influence the response to a subsequent pulmonary infection. We have previously published that alternative macrophage activation can alter pulmonary immune responses to extracellular bacterial infection in a mouse model (Feola et al., 2010). To determine the impact of Pneumocystis infection upon the immune response to secondary bacterial pneumonia, we infected mice with $P$. aeruginosa incorporated into agarose beads 14 days after they had been infected with Pneumocystis. We chose this design because our macrophage polarization data suggests that there is a prevalence of alternative macrophage characteristics at this point (Fig. 2). In response to Pseudomonas infection, an increase in lung arginase concentrations in animals co-infected with Pneumocystis was observed at day 3 , with persistence through day 10 post-infection (Fig. 5A), although the differences between infected groups were not statistically significant at the latter timepoint. Overall numbers of total cells, CD11 $\mathrm{b}^{+}$cells, and $\mathrm{CD} 11 \mathrm{c}^{+}$cells in the lung digest were similar over time among groups. We observed an increase in the number of $\mathrm{CD}_{11} \mathrm{~b}^{+}$cells in the alveolar space, reflected in a significant increase in $\mathrm{CD} 11 \mathrm{~b}^{+} \mathrm{MR}^{+}$cells at the day 0 timepoint, before infecting with $P$. aeruginosa (Fig. 5B). On day 3 post- $P$. aeruginosa infection, the numbers of $\mathrm{CD} 11 \mathrm{~b}^{+} \mathrm{MR}^{+}$cells were significantly higher in the lung lavage $(\mathrm{p}<0.01)$ and lung digest $(\mathrm{p}<0.01)$ of the mice who had previously been infected with Pneumocystis. By day 10 postinfection, MR expression on $\mathrm{CD}_{11} \mathrm{~b}^{+}$cells was back to baseline levels in both groups. We also observed a simultaneous increase in the classical activation marker CD80 in animals that had been dually infected on day 3 post-infection with $P$. aeruginosa (Fig. 5B).

Consistent with data from previous figures, and from studies in other disease models, these results suggest that overall macrophage populations have increased expression of proteins characteristic of both classical and alternative activation (Shirey et al., 2010).

Both $\mathrm{CD} 11 \mathrm{~b}^{+}$and $\mathrm{CD} 11 \mathrm{c}^{+}$subsets were examined by intracellular cytokine staining on days 3 and 10 post- $P$. aeruginosa infection (Fig. $5 \mathrm{C}$ ). While there was a trend of an increase in the number of cells producing the pro-inflammatory cytokine TNF- $a$ in the dually infected mice, differences between groups were not statistically significant due to a large amount of variability (effect over time $\mathrm{p}=0.154$ by 2 -way ANOVA). The number of $\mathrm{CD} 11 \mathrm{~b}^{+}$cells producing TGF- $\beta$ trended towards a significant increase in the dually infected group on both day 3 and day 10 post infection. The difference in CD11 $\mathrm{c}^{+}$cell production of TGF- $\beta$ was 
significantly higher in the dual infection group on day 3, as shown in Fig. 5D. The number of cells producing IL-10 was also increased in the mice previously infected with Pneumocystis, most notably in the CD11c $\mathrm{c}^{+}$subset. However, this increase was not statistically significant. These data confirm that Pneumocystis infection alters the set-point of macrophage activation, most notably in the more regulatory cytokines TGF- $\beta$ and IL-10, which lead to an alteration in response to the subsequent bacterial infection. It is important to note here that some cells in the $\mathrm{CD} 11 \mathrm{c}^{+}$subset are likely dendritic cells, which also can produce IL-10.

Clearance kinetics are shown for $P$. aeruginosa pooled across experiments in Fig. 5E. No significant differences were found between groups. All animals in all replicates were close to having cleared the bacteria from the lungs by day 10 , regardless of treatment group. The percentage of weight change is also shown for data pooled from these experiments (Fig. 5F). While no differences on any individual day were significant, the overall weight curves were different between groups ( $\mathrm{p}=0.009,2$-way ANOVA), demonstrating a more severe weight loss in the group previously infected with Pneumocystis.

\section{Discussion}

In this report, we show that Pneumocystis skews the population of macrophages in the lungs to acquire an alternatively-activated phenotype. Macrophages from IL-4Ra ${ }^{-1-}$ animals were restricted in their ability to up-regulate these markers to the same extent as WT animals, and gene expression for the AAM genes FIZZ1, arg1, and $Y m 1$ were virtually non-existent. Pneumocystis-induced AAM polarization persisted beyond clearance of the organism, and was shown to modulate a subsequent immune response to $P$. aeruginosa. Our results suggest that the presence of Pneumocystis alters the overall pulmonary macrophage population, a polarization that requires signaling through the IL-4Ra to reach its full effect, and influences subsequent challenges to pulmonary immunity.

Recently there has been increased recognition of Pneumocystis colonization and infection in smokers and patients with COPD (Morris et al., 2004a; Morris et al., 2008b; Norris et al., 2011). Because of the association of Pneumocystis and advanced fibrotic processes that occur in these patients, we explored the hypothesis that the organism could influence the pulmonary environment through its effect on macrophage activation. COPD is generally thought to be a consequence of an abnormal response in the lungs to inhaled toxic particles and gases, including cigarette smoke (Hogg et al., 2009). While all smokers display low level inflammation in the lungs, a small subset of patients experience exacerbated responses to environmental stimuli resulting in an amplified inflammatory response and a large scale remodeling process that results in the lung lesions and airway obstruction that are characteristic of COPD (Hogg et al., 1994; Wright et al., 1984). Indeed, studies indicate that acute exacerbations of COPD are attributed to viruses, Mycoplasma, and other infectious entities (Seemungal et al., 2001; Smith et al., 1980). A more recent report analyzing the gene expression of 18 subjects with COPD who were colonized with Pneumocystis compared to a group of 193 subjects who were not colonized, demonstrated that colonized patients had upregulated IFN $\gamma$ and other genes predominantly associated with Th1-polarized T lymphocytes (Fitzpatrick et al., 2014). Our data suggests that the presence of Pneumocystis 
in these patients may cause modulation of the host immune response in the lungs, thereby altering inflammation, airway remodeling, or both.

Alveolar macrophages play a critical role in the uptake and degradation of Pneumocystis (Ezekowitz et al., 1991; Limper et al., 1997; Masur et al., 1978; O'Riordan et al., 1995). The heterogeneous nature of the macrophage lineage lends difficulty to phenotypic and functional characterization. In the first two weeks following Pneumocystis infection, investigators have observed a greater number of IL- 4 secreting $\mathrm{CD}^{+} \mathrm{T}$ cells in comparison to $\mathrm{CD}^{+}{ }^{+} \mathrm{T}$ cells secreting IFN $\gamma$ (Nelson et al., 2011; Shellito et al., 2000). Similarly other Th2 cytokines, IL-5 and IL-13, are elevated in the BAL between days 3 and 14 after infection with Pneumocystis (Meissner et al., 2005; Nelson et al., 2011), and this corresponds with robust levels of IL-10 produced early following infection (Meissner et al., 2005). Elevated levels of these cytokines suggest that Pneumocystis infection induces an environment that is favorable to elicit generation of AAM. Additionally, a recent study of immune modulation using sulfasalazine demonstrates that this anti-inflammatory agent increases Th2 and AAM polarization, which corresponds with an increase in phagocytosis and clearance of Pneumocystis (Wang et al., 2010). Our data supports these studies, showing that Pneumocystis induces an AAM phenotype within 4 hours of exposure in culture and within 4 days in vivo. It is possible that polarization towards this phenotype comes at the cost of an alteration in pulmonary immunity that can, at the very least, last for several days.

A study by Nelson et al. indicated that AAM polarization results in an enhanced clearance of Pneumocystis (Nelson et al., 2011). In mice deficient in the myeloid Src-family tyrosine kinases Hck, Fgr, and Lyn (Src triple knockout (TKO)), they report that the enhanced clearance of Pneumocystis from the lungs (Nelson et al., 2009) is associated with this strain's heightened AAM polarization (Nelson et al., 2011). The Src TKO mice displayed alveolar macrophages with enhanced production of FIZZ-1 and arginase 1, along with the AAM-associated chemokines CCL17, CCL22, and IL-33. A member of the IL-1 family, IL-33 acts in concert with IL-13 signaling through IL-4Ra to further up-regulate arginase 1, Ym1, and MR expression on macrophages during airway inflammation (KurowskaStolarska et al., 2009). In addition, they demonstrated that treatment with exogenous IL-33 in normal C57Bl/6 mice results in up-regulation of AAM-markers in mice infected with Pneumocystis, and enhanced the phagocytosis of the organism in vitro and its clearance from the lungs in vivo (Nelson et al., 2011). These data support the notion that alternative macrophage activation is likely playing a functional role in the response and clearance of Pneumocystis.

In the current study, our work focuses instead on the effects of the organism upon macrophage polarization during a normal response. While Nelson et. al. demonstrated dramatic increases in AAM polarization in the experimental mouse models, their control animals also exhibited moderate up-regulation of AAM-associated proteins, including arginase and FIZZ-1 (Nelson et al., 2011). Comparing across studies, it appears that the production of these proteins occurred to a higher degree on day 7 post-infection in the $\mathrm{BALB} / \mathrm{c}$ mice utilized in our work, as compared to the control strain utilized in their work (C57B1/6). This distinction may lie in the phenotypic differences associated with these mice with regards to their biases in $\mathrm{T}$ cell polarization, with $\mathrm{BALB} / \mathrm{c}$ mice more adept at Th2-type 
responses. Indeed, response to Pneumocystis includes both Th1 and Th2 subsets, with the organism inducing a higher number of T cells to produce IL-4 than IFN $\gamma$ in a normal response (Shellito et al., 2000). A recent study from this group showed that Stat $4^{-/-}$mice on a C57B1/6 background controlled Pneumocystis growth better than Stat $4^{-/-}$mice on a BALB/c background, which did not exhibit an AAM response (Myers et al., 2013). The Nelson study additionally shows no difference in the production of IL-4 or IL-13 in the Src TKO mice as compared to the normal control mice (Nelson et al., 2011), a finding that is supported by our results that show alternative macrophage polarization to be achieved in response to Pneumocystis infection, albeit to a lesser degree, in mice that lack functional signaling through the IL-4 and IL-13 receptors.

A recent study by Zhang et al. demonstrates that mice lacking in either CAM or AAM responses still possess the ability to clear Pneumocystis (Zhang et al., 2015). By crossing IFN $\gamma \mathrm{R}^{-/-}$mice or IL4ra ${ }^{-/-}$mice to RAG2 ${ }^{-/-}$animals, and then providing WT T cells by adoptive transfer, they demonstrated that in the setting of immune reconstitution inflammatory syndrome (IRIS), neither CAM or AAM were required for the clearance of Pneumocystis. However, while all strains were able to clear the organism, mice that lacked a CAM response ( $\mathrm{RAG}^{-/-} / \mathrm{IFN} \mathrm{R}^{-/}$) had increased Pneumocystis-related immunopathologies (Zhang et al., 2015). Our results correspond with theirs in that the lack of signaling through the IL4ra to restrict AAM responses did not impact the clearance kinetics of the organism. There are important differences between studies, as our mice also lack IL4ra on T cells, and in the Zhang study the mice were undergoing immune reconstitution, which can in itself cause immunopathology (Bonham et al., 2008). Key elements to the response in the mice that lacked IFN $\gamma \mathrm{R}$ included impaired $\mathrm{CD} 8^{+} \mathrm{T}$ cell regulatory function and elevated concentrations of IFN $\gamma$ (Zhang et al., 2015). Indeed, these results support that there is a complex balance of macrophage and T cell phenotypic responses needed in order to produce an optimal situation of organism clearance and limited pulmonary pathology.

Our results that show Pneumocystis infection alters the subsequent response to infection with the extracellular Gram-negative bacterial pathogen $P$. aeruginosa are of significant importance. Our previous studies demonstrate that treatment of mice with azithromycin, an azalide antimicrobial agent that was demonstrated to induce alternative macrophage activation in vitro (Murphy et al., 2008), increases in AAM properties by day 7 postinfection (including a significantly higher production of arginase) led to a decrease in mortality and blunted peribronchiolar inflammation in C57B1/6 mice infected with $P$. aeruginosa (Feola et al., 2010). Therefore, because Pneumocystis can induce prolonged alterations in the polarization set-point of alveolar and interstitial macrophages, subsequent responses may be altered, leading to an impact on the pathology of chronic inflammatory lung conditions. It is possible that AAM could function to control exaggerated aspects of immune responses that accompany these conditions through a variety of mechanisms. These include direct suppression of CAM-driven inflammatory processes, control of neutrophil recruitment, or suppression of T lymphocyte responses (Kahnert et al., 2006; Katakura et al., 2004; Muller et al., 2007; Weber et al., 2007; Weng et al., 2007). 
The robust up-regulation of arginase expression and activity following exposure to Pneumocystis warrants investigation of the role of this mediator during infection. While arginase-1 is known primarily for its role in the coordination of extracellular matrix protein production that can result in pulmonary remodeling, it also is involved in limiting inflammation. El Kasmi and colleagues demonstrated that in intracellular infection models in mice lacking arginase-1 expression, NO production is enhanced, resulting in reduced bacterial burdens and lower morbidity to both Mycobacterium species and Toxoplasma gondii (El Kasmi et al., 2008). In contrast to these findings, macrophage-specific expression of arginase- 1 has been shown to regulate the aspects of Th2-driven pathologies such as infection with $S$. mansoni (Herbert et al., 2010; Pesce et al., 2009a). Mice with macrophages that lack Arg1 succumb to the associated Th2-driven pathology in this model of infection (Herbert et al., 2010). In another model, AAMs were required to limit inflammatory pathology associated with RSV infection in mice (Shirey et al., 2010). Studies showed that TLR4-mediated RSV-associated Th1-type inflammatory cytokine production was regulated by AAM. In addition to cytokine production, these investigators showed that RSV-infected IL-4ra ${ }^{-1-}$ mice, which lack substantial arginase-1 expression and blunted AAM responses, displayed increased peribronchiolar inflammation (Shirey et al., 2010). These studies demonstrate the detrimental consequences that can occur in the absence of AAM effectors.

While the production of arginase was blunted in alveolar macrophages isolated from IL-4ra ${ }^{-1}$ mice, and expression of mRNA for the AAM-associated genes arg1, FIZZ-1, and $Y m 1$ were very low in these animals 7 days after being infected with Pneumocystis, arginase protein expression was still detected, albeit at a lower level, both in vitro and in vivo. In light of the fact that Pneumocystis burdens were not affected in the IL-4ra ${ }^{-/}$mice, it is possible that the lower degree of alternative macrophage activation and expression of the associated effector proteins is enough to elicit the clearance of Pneumocystis. Importantly, the deletion of IL-4ra on T cells could also be contributing to the reduction in arginase activation and macrophage activation (Dewals et al., 2009). This will be the subject of future investigations.

Overall, our data suggests that the immune consequences of exposure to Pneumocystis may not be as innocuous in immunocompetent hosts as once thought. Our studies demonstrate that Pneumocystis has the capability to polarize primary macrophages towards an alternatively-activated phenotype in an IL-4Ra-dependent manner. This phenomenon occurs in a way that can influence subsequent infections and pulmonary insults. The extended kinetics of this phenomenon warrants further examination and provides impetus for further exploration Pneumocystis-mediated immunomodulation within the lungs of both healthy and diseased patients.

\section{Acknowledgments}

Research reported in this publication was supported by the National Heart Lung and Blood Institute of the National Institutes of Health under Award Number R01HL088989 to B.A.G, and by the National Institute of Allergy and Infectious Diseases under Award Number R01AI095307 to D.J.F. The funding sources played no role in the study design, data analysis/interpretation, the writing of the report, or the decision to submit the manuscript.

We also acknowledge the expert technical assistance of M L. Hollifield. 


\section{Abbreviations \\ COPD chronic obstructive pulmonary disease \\ CF cystic fibrosis \\ CAM classically activated macrophage \\ AAM alternatively activated macrophage \\ BAL bronchoalveolar lavage \\ MR mannose receptor \\ CFU colony forming unit \\ TSB trypticase soy broth \\ EDTA ethylenediaminetetraacetic acid \\ MOI multiplicity of infection \\ FBS fetal bovine serum \\ ANOVA analysis of variance}

\section{References}

Bansal V, Ochoa JB. Arginine availability, arginase, and the immune response. Curr Opin Clin Nutr Metab Care. 2003; 6:223-228. [PubMed: 12589193]

Bernard AC, Fitzpatrick EA, Maley ME, Gellin GL, Tsuei BJ, Arden WA, Boulanger BR, Kearney PA, Ochoa JB. Beta adrenoceptor regulation of macrophage arginase activity. Surgery. 2000; 127:412418. [PubMed: 10776432]

Bonham S, Meya DB, Bohjanen PR, Boulware DR. Biomarkers of HIV Immune Reconstitution Inflammatory Syndrome. Biomark Med. 2008; 2:349-361. [PubMed: 19057654]

Calderon EJ, Friaza V, Dapena FJ, de La Horra C. Pneumocystis jirovecii and cystic fibrosis. Med Mycol. 2010; 48(Suppl 1):S17-S21. [PubMed: 21067325]

Corraliza IM, Soler G, Eichmann K, Modolell M. Arginase induction by suppressors of nitric oxide synthesis (IL-4, IL-10 and PGE2) in murine bone-marrow-derived macrophages. Biochem Biophys Res Commun. 1995; 206:667-673. [PubMed: 7530004]

Dewals B, Hoving JC, Leeto M, Marillier RG, Govender U, Cutler AJ, Horsnell WG, Brombacher F. IL-4Ralpha responsiveness of non-CD4 T cells contributes to resistance in schistosoma mansoni infection in pan-T cell-specific IL-4Ralpha-deficient mice. Am J Pathol. 2009; 175:706-716. [PubMed: 19628763]

El Kasmi KC, Qualls JE, Pesce JT, Smith AM, Thompson RW, Henao-Tamayo M, Basaraba RJ, Konig T, Schleicher U, Koo MS, Kaplan G, Fitzgerald KA, Tuomanen EI, Orme IM, Kanneganti TD, Bogdan C, Wynn TA, Murray PJ. Toll-like receptor-induced arginase 1 in macrophages thwarts effective immunity against intracellular pathogens. Nat Immunol. 2008; 9:1399-1406. [PubMed: 18978793]

Ezekowitz RA, Williams DJ, Koziel H, Armstrong MY, Warner A, Richards FF, Rose RM. Uptake of Pneumocystis carinii mediated by the macrophage mannose receptor. Nature. 1991; 351:155-158. [PubMed: 1903183]

Feola DJ, Garvy BA, Cory TJ, Birket SE, Hoy H, Hayes D Jr, Murphy BS. Azithromycin alters macrophage phenotype and pulmonary compartmentalization during lung infection with Pseudomonas. Antimicrob Agents Chemother. 2010; 54:2437-2447. [PubMed: 20231397] 
Fitzpatrick ME, Tedrow JR, Hillenbrand ME, Lucht L, Richards T, Norris KA, Zhang Y, Sciurba FC, Kaminski N, Morris A. Pneumocystis jirovecii colonization is associated with enhanced Th1 inflammatory gene expression in lungs of humans with chronic obstructive pulmonary disease. Microbiol Immunol. 2014; 58:202-211. [PubMed: 24438206]

Friaza V, la Horra C, Rodriguez-Dominguez MJ, Martin-Juan J, Canton R, Calderon EJ, Del Campo R. Metagenomic analysis of bronchoalveolar lavage samples from patients with idiopathic interstitial pneumonia and its antagonic relation with Pneumocystis jirovecii colonization. J Microbiol Methods. 2010; 82:98-101. [PubMed: 20382190]

Gordon S. Alternative activation of macrophages. Nat Rev Immunol. 2003; 3:23-35. [PubMed: 12511873]

Herbert DR, Holscher C, Mohrs M, Arendse B, Schwegmann A, Radwanska M, Leeto M, Kirsch R, Hall P, Mossmann H, Claussen B, Forster I, Brombacher F. Alternative macrophage activation is essential for survival during schistosomiasis and downmodulates Thelper 1 responses and immunopathology. Immunity. 2004; 20:623-635. [PubMed: 15142530]

Herbert DR, Orekov T, Roloson A, Ilies M, Perkins C, O’Brien W, Cederbaum S, Christianson DW, Zimmermann N, Rothenberg ME, Finkelman FD. Arginase I suppresses IL-12/IL-23p40-driven intestinal inflammation during acute schistosomiasis. J Immunol. 2010; 184:6438-6446. [PubMed: 20483789]

Hogg JC, Wright JL, Wiggs BR, Coxson HO, Opazo Saez A, Pare PD. Lung structure and function in cigarette smokers. Thorax. 1994; 49:473-478. [PubMed: 8016769]

Hogg JC, Timens W. The pathology of chronic obstructive pulmonary disease. Annu Rev Pathol. 2009; 4:435-459. [PubMed: 18954287]

Kahnert A, Seiler P, Stein M, Bandermann S, Hahnke K, Mollenkopf H, Kaufmann SH. Alternative activation deprives macrophages of a coordinated defense program to Mycobacterium tuberculosis. Eur J Immunol. 2006; 36:631-647. [PubMed: 16479545]

Katakura T, Miyazaki M, Kobayashi M, Herndon DN, Suzuki F. CCL17 and IL-10 as Effectors That Enable Alternatively Activated Macrophages to Inhibit the Generation of Classically Activated Macrophages. J Immunol. 2004; 172:1407-1413. [PubMed: 14734716]

Kondo M, Takeshita T, Ishii N, Nakamura M, Watanabe S, Arai K, Sugamura K. Sharing of the interleukin-2 (IL-2) receptor gamma chain between receptors for IL-2 and IL-4. Science. 1993; 262:1874-1877. [PubMed: 8266076]

Kurowska-Stolarska M, Stolarski B, Kewin P, Murphy G, Corrigan CJ, Ying S, Pitman N, Mirchandani A, Rana B, van Rooijen N, Shepherd M, McSharry C, McInnes IB, Xu D, Liew FY. IL-33 amplifies the polarization of alternatively activated macrophages that contribute to airway inflammation. J Immunol. 2009; 183:6469-6477. [PubMed: 19841166]

Limper AH, Hoyte JS, Standing JE. The role of alveolar macrophages in Pneumocystis carinii degradation and clearance from the lung. J Clin Invest. 1997; 99:2110-2117. [PubMed: 9151783]

Mantovani A, Sozzani S, Locati M, Allavena P, Sica A. Macrophage polarization: tumor-associated macrophages as a paradigm for polarized M2 mononuclear phagocytes. Trends Immunol. 2002; 23:549-555. [PubMed: 12401408]

Masur H, Jones TC. The interaction in vitro of Pneumocystis carinii with macrophages and L-cells. J Exp Med. 1978; 147:157-170. [PubMed: 342665]

Meissner NN, Swain S, Tighe M, Harmsen A, Harmsen A. Role of Type I IFNs in Pulmonary Complications of Pneumocystis murina Infection. J Immunol. 2005; 174:5462-5471. [PubMed: 15843544]

Modolell M, Corraliza IM, Link F, Soler G, Eichmann K. Reciprocal regulation of the nitric oxide synthase/arginase balance in mouse bone marrow-derived macrophages by TH1 and TH2 cytokines. Eur J Immunol. 1995; 25:1101-1104. [PubMed: 7537672]

Montaner LJ, da Silva RP, Sun J, Sutterwala S, Hollinshead M, Vaux D, Gordon S. Type 1 and type 2 cytokine regulation of macrophage endocytosis: differential activation by IL-4/IL-13 as opposed to IFN-gamma or IL-10. J Immunol. 1999; 162:4606-4613. [PubMed: 10202000]

Morris A, Huang L, Bacchetti P, Turner J, Hopewell P, Wallace J, Kvale P, Rosen M, Glassroth J, Reichman L, Stansell J. Pulmonary Complications of HIV Infection Study Group. Permanent 
declines in pulmonary function following pneumonia in human immunodeficiency virus-infected person. Am J Respir Crit Care Med. 2000; 162:612-616. [PubMed: 10934095]

Morris A, Lundgren JD, Masur H, Walzer PD, Hanson DL, Frederick T, Huang L, Beard CB, Kaplan JE. Current epidemiology of Pneumocystis pneumonia. Emerg Infect Dis. 2004a; 10:1713-1720. [PubMed: 15504255]

Morris A, Sciurba C, Lebedeva IP, Githaiga A, Elliott WM, Hogg JC, Huang L, Norris KA. Association of chronic obstructive pulmonary disease severity and Pneumocystis colonization. Am. J. Respir. Crit. Care Med. 2004b; 178:408-413.

Morris A, Netravali M, Kling HM, Shipley T, Ross T, Sciurba FC, Norris KA. Relationship of Pneumocystis Antibody Response to Severity of Chronic Obstructive Pulmonary Disease. Clinical Infectious Diseases. 2008a; 47:e64. [PubMed: 18724825]

Morris A, Sciurba FC, Norris KA. Pneumocystis: A Novel Pathogen in Chronic Obstructive Pulmonary Disease? COPD: Journal of Chronic Obstructive Pulmonary Disease. 2008b; 5:43-51. [PubMed: 18259974]

Muller U, Stenzel W, Kohler G, Werner C, Polte T, Hansen G, Schutze N, Straubinger RK, Blessing M, McKenzie AN, Brombacher F, Alber G. IL-13 induces disease-promoting type 2 cytokines, alternatively activated macrophages and allergic inflammation during pulmonary infection of mice with Cryptococcus neoformans. J Immunol. 2007; 179:5367-5377. [PubMed: 17911623]

Munder M, Eichmann K, Modolell M. Alternative metabolic states in murine macrophages reflected by the nitric oxide synthase/arginase balance: competitive regulation by CD4+ T cells correlates with Th1/Th2 phenotype. J Immunol. 1998; 160:5347-5354. [PubMed: 9605134]

Murphy BS, Sundareshan V, Cory TJ, Hayes D Jr, Anstead MI, Feola DJ. Azithromycin alters macrophage phenotype. J. Antimicrob. Chemother. 2008; 61:554-560.

Myers RC, Dunaway CW, Nelson MP, Trevor JL, Morris A, Steele C. STAT4-Dependent and Independent Th2 Responses Correlate with Protective Immunity against Lung Infection with Pneumocystis murina. J Immunol. 2013; 190:6287-6294. [PubMed: 23650614]

Nacucchio MC, Cerquetti MC, Meiss RP, Sordelli DO. Short communication. Role of agar beads in the pathogenicity of Pseudomonas aeruginosa in the rat respiratory tract. Pediatr Res. 1984; 18:295296. [PubMed: 6728563]

Nelms K, Keegan AD, Zamorano J, Ryan JJ, Paul WE. The IL-4 receptor: signaling mechanisms and biologic functions. Annu Rev Immunol. 1999; 17:701-738. [PubMed: 10358772]

Nelson MP, Metz AE, Li S, Lowell CA, Steele C. The absence of Hck, Fgr, and Lyn tyrosine kinases augments lung innate immune responses to Pneumocystis murina. Infect Immun. 2009; 77:17901797. [PubMed: 19255189]

Nelson MP, Christmann BS, Werner JL, Metz AE, Trevor JL, Lowell CA, Steele C. IL-33 and M2a alveolar macrophages promote lung defense against the atypical fungal pathogen Pneumocystis murina. J Immunol. 2011; 186:2372-2381. [PubMed: 21220696]

Norris KA, Morris A. Pneumocystis infection and the pathogenesis of chronic obstructive pulmonary disease. Immunol Res. 2011; 50:175-180. [PubMed: 21717077]

O'Riordan D, Standing J, Limper A. Pneumocystis carinii glycoprotein a binds macrophage mannose receptors. Infect Immun. 1995; 63:779-784. [PubMed: 7868247]

Pesce JT, Ramalingam TR, Mentink-Kane MM, Wilson MS, El Kasmi KC, Smith AM, Thompson RW, Cheever AW, Murray PJ, Wynn TA. Arginase-1-expressing macrophages suppress Th2 cytokine-driven inflammation and fibrosis. PLoS Pathog. 2009a; 5:e1000371. [PubMed: 19360123]

Pesce JT, Ramalingam TR, Wilson MS, Mentink-Kane MM, Thompson RW, Cheever AW, Urban JF Jr, Wynn TA. Retnla (relmalpha/fizz1) suppresses helminth-induced Th2-type immunity. PLoS Pathog. 2009b; 5:e1000393. [PubMed: 19381262]

Qureshi MH, Cook-Mills J, Doherty DE, Garvy BA. TNF-\{alpha\}-Dependent ICAM-1- and VCAM-1-Mediated Inflammatory Responses Are Delayed in Neonatal Mice Infected with Pneumocystis carinii. J Immunol. 2003a; 171:4700-4707. [PubMed: 14568945]

Qureshi MH, Harmsen AG, Garvy BA. IL-10 Modulates Host Responses and Lung Damage Induced by Pneumocystis carinii Infection. J Immunol. 2003b; 170:1002-1009. [PubMed: 12517967] 
Ralph P, Nakoinz I. Phagocytosis and cytolysis by a macrophage tumour and its cloned cell line. Nature. 1975; 257:393-394. [PubMed: 1101071]

Russell SM, Keegan AD, Harada N, Nakamura Y, Noguchi M, Leland P, Friedmann MC, Miyajima A, Puri RK, Paul WE, Leonard WJ. Interleukin-2 receptor gamma chain: a functional component of the interleukin-4 receptor. Science. 1993; 262:1880-1883. [PubMed: 8266078]

Seemungal T, Harper-Owen R, Bhowmik A, Moric I, Sanderson G, Message S, Maccallum P, Meade TW, Jeffries DJ, Johnston SL, Wedzicha JA. Respiratory viruses, symptoms, and inflammatory markers in acute exacerbations and stable chronic obstructive pulmonary disease. Am J Respir Crit Care Med. 2001; 164:1618-1623. [PubMed: 11719299]

Shellito JE, Tate C, Ruan S, Kolls J. Murine CD4+ T lymphocyte subsets and host defense against Pneumocystis carinii. J Infect Dis. 2000; 181:2011-2017. [PubMed: 10837183]

Shirey KA, Pletneva LM, Puche AC, Keegan AD, Prince GA, Blanco JC, Vogel SN. Control of RSVinduced lung injury by alternatively activated macrophages is IL-4R alpha-, TLR4-, and IFN-betadependent. Mucosal Immunol. 2010; 3:291-300. [PubMed: 20404812]

Sing A, Geiger A, Hogardt M, Heesemann J. Pneumocystis carinii carriage among cystic fibrosis patients, as detected by nested PCR. J Clin Microbiol. 2001; 39:2717-2718. [PubMed: 11427604]

Smith CB, Kanner RE, Golden CA, Klauber MR, Renzetti AD Jr. Effect of viral infections on pulmonary function in patients with chronic obstructive pulmonary diseases. J Infect Dis. 1980; 141:271-280. [PubMed: 6767794]

Stout RD, Suttles J. Functional plasticity of macrophages: reversible adaptation to changing microenvironments. J Leukoc Biol. 2004; 76:509-513. [PubMed: 15218057]

van Heeckeren AM, Schluchter MD. Murine models of chronic Pseudomonas aeruginosa lung infection. Lab Anim. 2002; 36:291-312. [PubMed: 12144741]

Wang J, Gigliotti F, Bhagwat SP, George TC, Wright TW. Immune modulation with sulfasalazine attenuates immunopathogenesis but enhances macrophage-mediated fungal clearance during Pneumocystis pneumonia. PLoS Pathog. 2010; 6:e1001058. [PubMed: 20808846]

Weber MS, Prod'homme T, Youssef S, Dunn SE, Rundle CD, Lee L, Patarroyo JC, Stuve O, Sobel RA, Steinman L, Zamvil SS. Type II monocytes modulate T cell-mediated central nervous system autoimmune disease. Nat Med. 2007; 13:935-943. [PubMed: 17676050]

Weng M, Huntley D, Huang IF, Foye-Jackson O, Wang L, Sarkissian A, Zhou Q, Walker WA, Cherayil BJ, Shi HN. Alternatively activated macrophages in intestinal helminth infection: effects on concurrent bacterial colitis. J Immunol. 2007; 179:4721-4731. [PubMed: 17878371]

Wilson MS, Wynn TA. Pulmonary fibrosis: pathogenesis, etiology and regulation. Mucosal Immunol. 2009; 2:103-121. [PubMed: 19129758]

Wright JL, Wiggs BJ, Hogg JC. Airway disease in upper and lower lobes in lungs of patients with and without emphysema. Thorax. 1984; 39:282-285. [PubMed: 6719374]

Wynn TA, Barron L. Macrophages: master regulators of inflammation and fibrosis. Semin Liver Dis. 2010; 30:245-257. [PubMed: 20665377]

Zhang ZQ, Wang J, Hoy Z, Keegan A, Bhagwat S, Gigliotti F, Wright TW. Neither classical nor alternative macrophage activation is required for Pneumocystis clearance during immune reconstitution inflammatory syndrome. Infect Immun. 2015; 83:4594-4603. [PubMed: 26371121] 

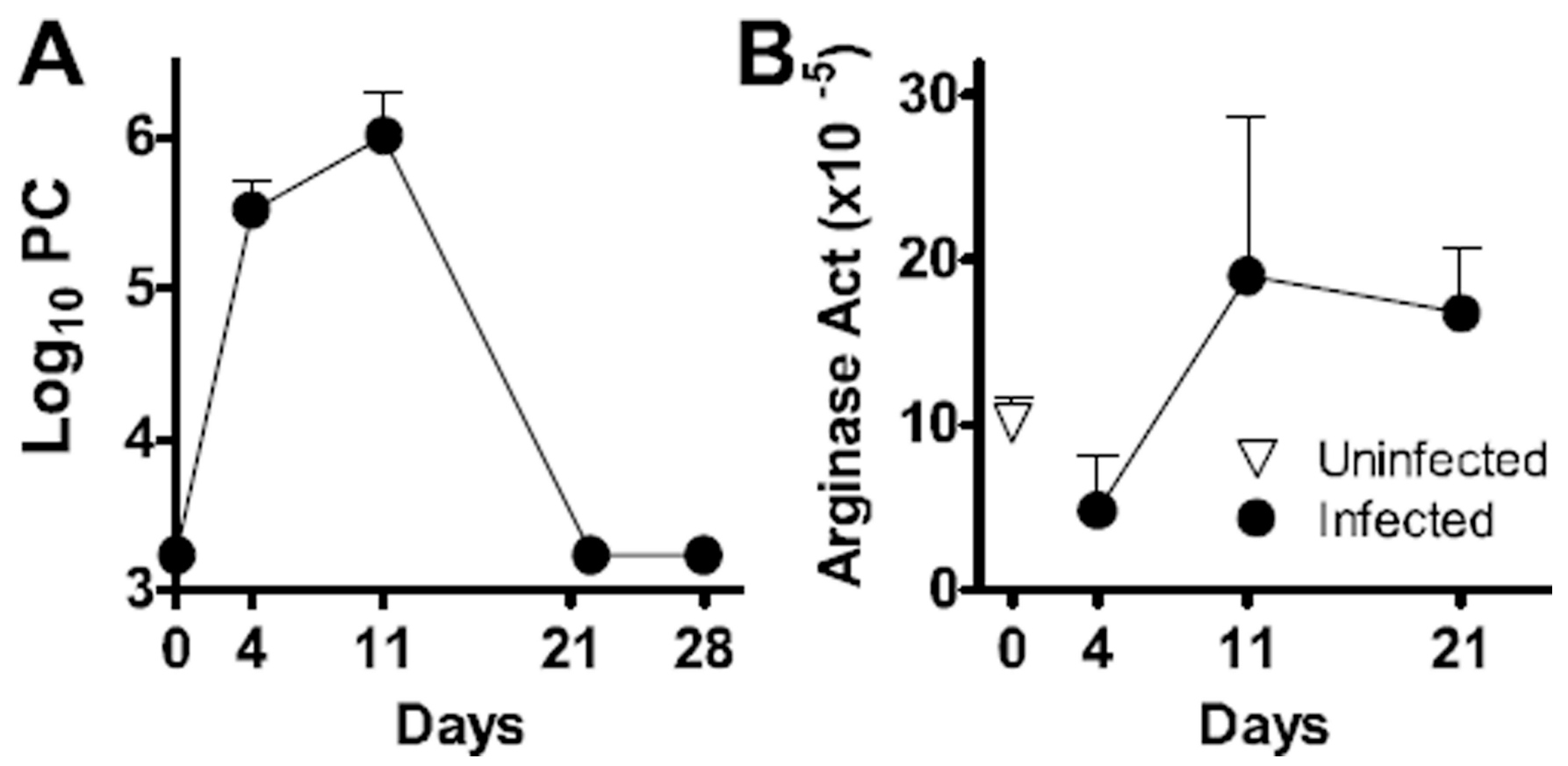

FIG 1.

Pneumocystis murina infection up-regulates production of arginase in vivo. BALB/c mice were infected with $1 \times 10^{7}$ Pneumocystis (PC) organisms by intratrachael instillation on day 0 and euthanized at post-infection time points. (A) Pneumocystis burden was assessed over time post-infection by microscopically counting organisms in lung digest preparations. (B) Arginase activity in lung digest preparations was determined by measurement of the conversion of arginine into urea and standardized to total protein. 

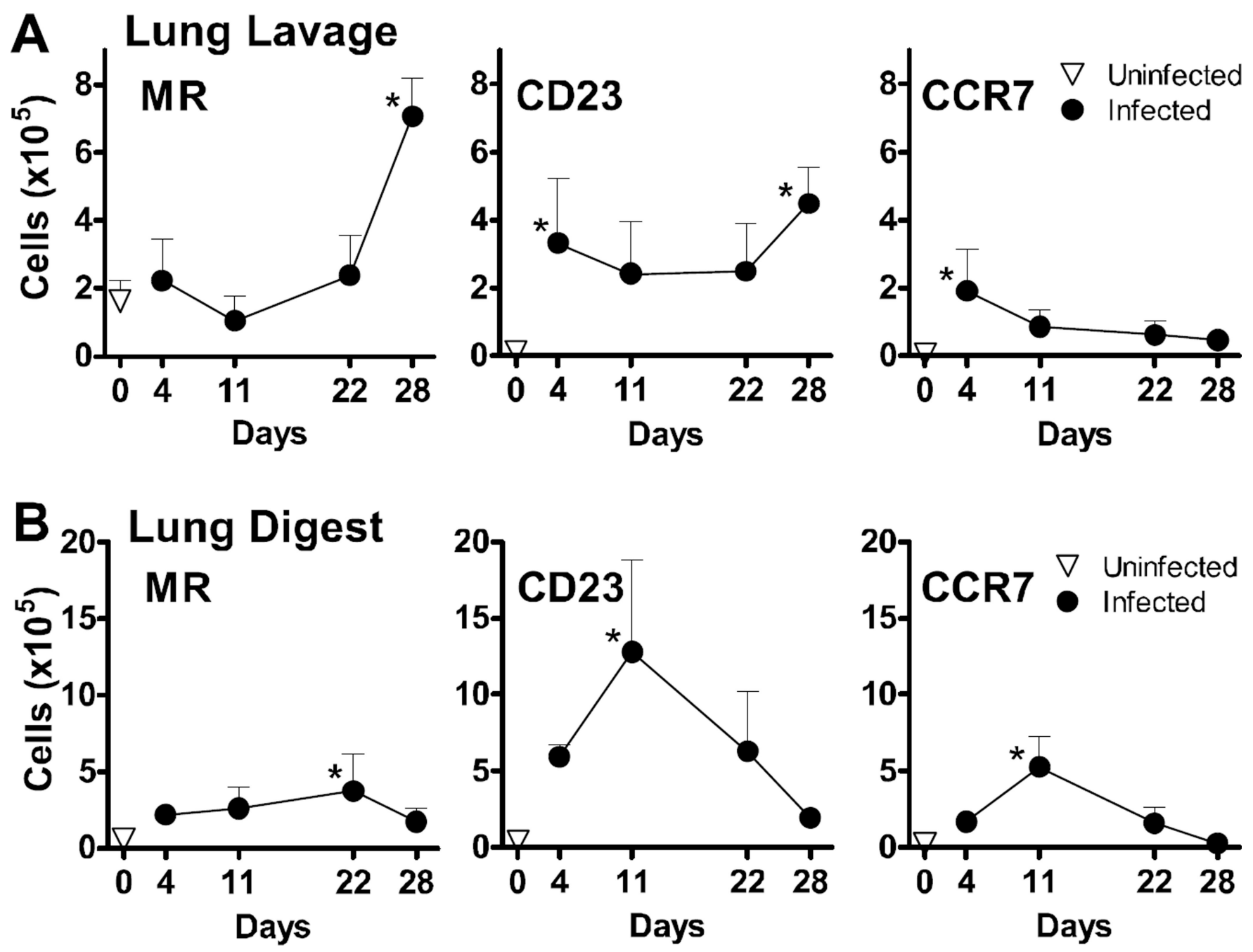

FIG 2.

Pneumocystis murina infection up-regulates the surface protein expression of alternative macrophage activation markers in vivo. Cells isolated from bronchoalveolar lavage (A) and lung digest (B) preparations from BALB/c mice isolated over time post-infection were enumerated and stained for cell surface expression of macrophage proteins and analyzed by flow cytometry. After gating out lymphocytes and dead cells by forward and side scatter characteristics, the number of cells within the $\mathrm{CD} 11 \mathrm{~b}^{+} \mathrm{GR} 1^{-}$gate that exhibited upregulation of MR, CCR7, and CD23 as compared to unstained controls were reported over time for each compartment. All graphs display mean \pm SD for 3-4 mice per group per timepoint, and results are representative of 2 experimental replicates. Values were compared using 1-way ANOVA and Dunnett's post-hoc analysis comparing means to that of an uninfected control group. Statistically significant differences between treatment groups indicated for $P<0.05$ (*). 


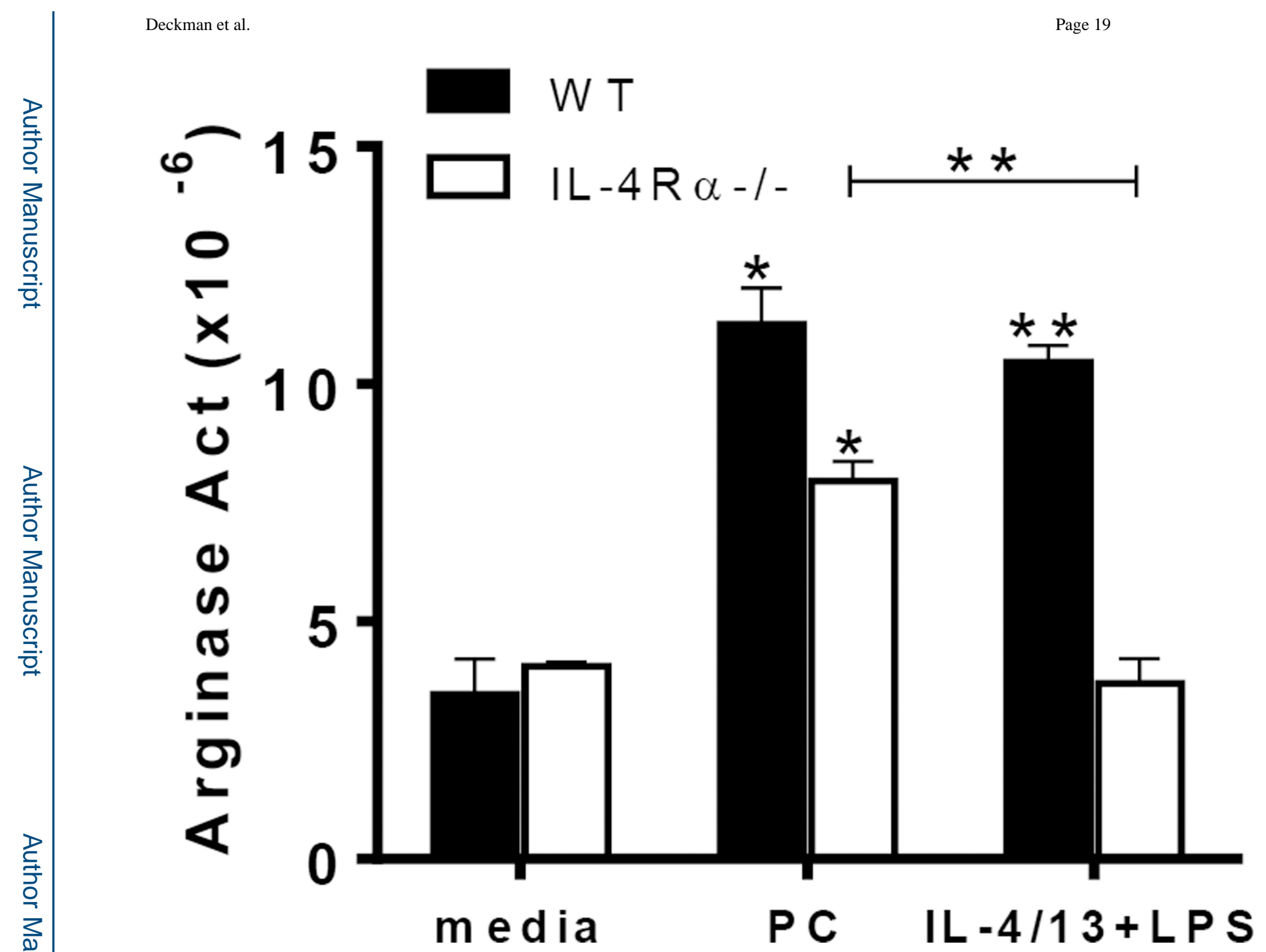

FIG 3.

Pneumocystis induces arginase expression in vitro in a partially IL-4Ra-dependent manner. Primary alveolar macrophages from BALB/c or IL-4 $\mathrm{Ra}^{-/-}$mice were cultured in quadruplicate in the presence of Pneumocystis (PC) organisms (MOI=10), IL-4/13+LPS, or media only and harvested after 24 hours. Cell lysates were collected and assayed for arginase activity as determined by measurement of the conversion of arginine into urea and standardized to total protein. Data is presented as fold increase compared to unstained controls for each cell type among CD $11 c^{+}$cells. Means \pm standard deviation are presented and are representative of 3 separate experiments. Statistically significant differences between treatment groups are denoted as follows: ${ }^{*}, P<0.05$ and $* *, P<0.01$ as analyzed one-way ANOVA and Bonferroni post test. Asterisks atop of bars indicate comparison to media control condition, with differences between Pneumocystis and IL-4/13 treatments denoted by brackets. 

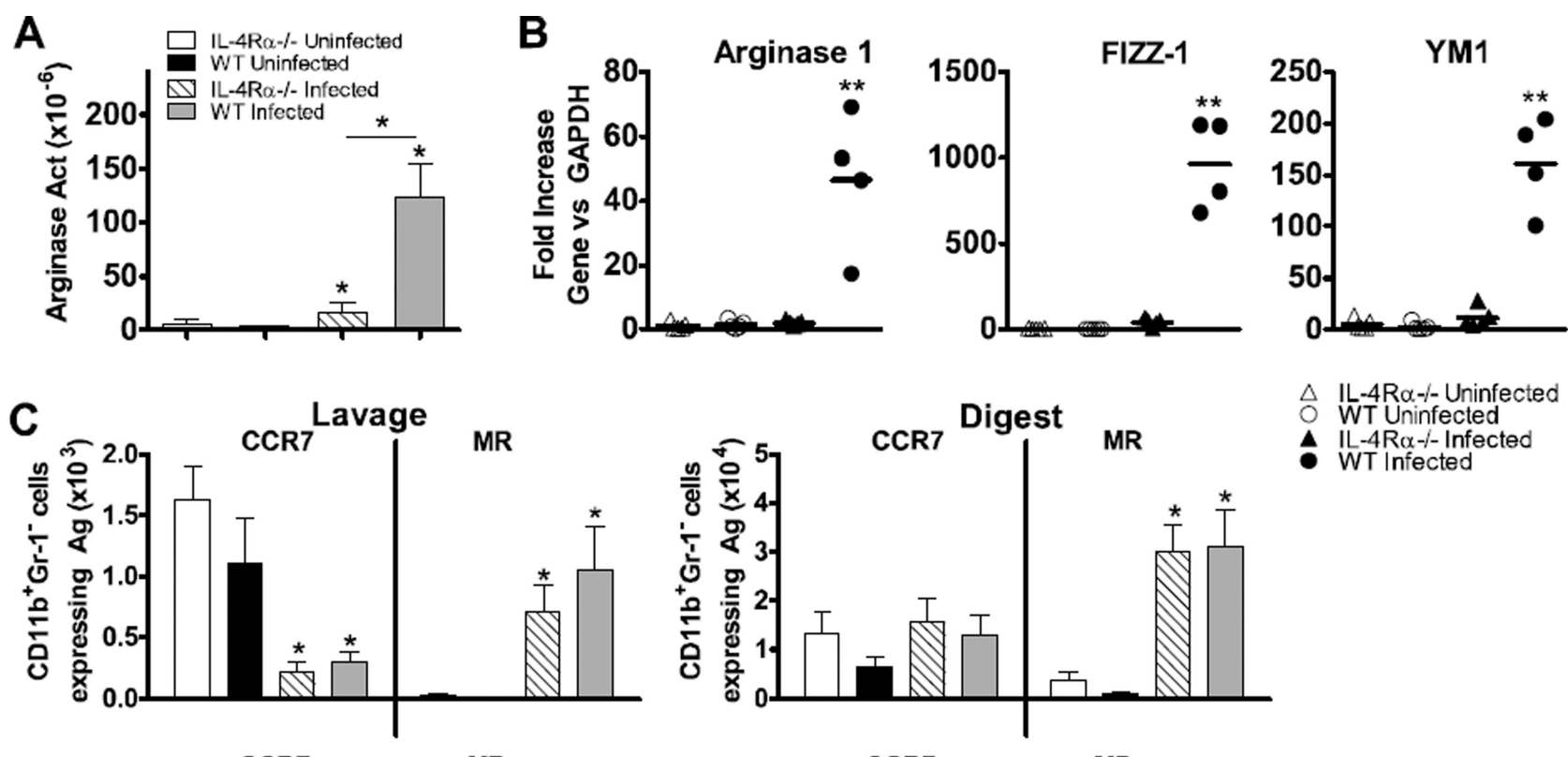

$\triangle$ IL-4R $\alpha-$ - - Uninfected

O WT Uninfected

I $\mathrm{L}-4 \mathrm{R} \alpha-$ - - Infected

- WTInfected
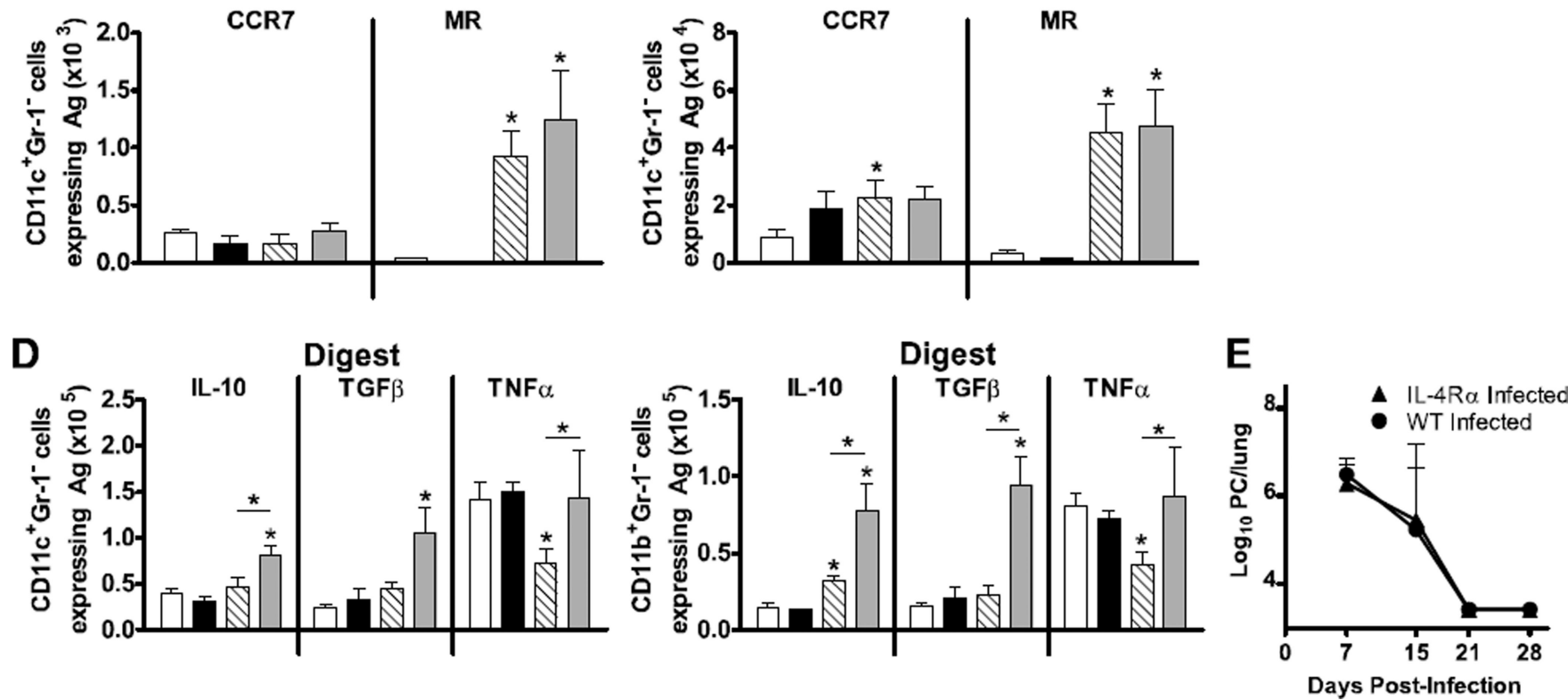

FIG 4.

Pneumocystis infection induces an AAM phenotype in vivo in an IL-4Ra-dependent manner. Wildtype BALB/c and IL-4Ra ${ }^{-/-}$mice were infected with $1 \times 10^{7}$ Pneumocystis (PC) nuclei by i.t. instillation and euthanized at 7 days post-infection. Cells were isolated from the alveolar space via lung lavage, and subsequently whole lungs were digested to create single cell suspensions. (A) Arginase activity in lung digest was determined by measurement of the conversion of arginine into urea and standardized to total protein. (B) mRNA was isolated from lung digest cells and reverse transcribed to cDNA. Gene expression was quantified using qPCR to determine gene expression levels of Arg1, Fizz1, and $Y m 1$ genes. qPCR data was normalized to values generated in wildtype uninfected animals and expressed as fold increase over controls. (C) Cells isolated from lung lavage and lung digest samples were stained for surface expression of CD11b, CD11c, Gr1, MR, and 
CCR7 and analyzed by flow cytometry. Cells that were $\mathrm{CD} 11 \mathrm{~b}^{+} \mathrm{Gr} 1^{-}$and $\mathrm{CD} 11 \mathrm{c}^{+} \mathrm{Gr} 1^{-}$were gated upon, and the numbers of cells in each subset expressing CCR7 or MR were determined in both the lung lavage and lung digest samples. (D) The number of $\mathrm{CD} 11 \mathrm{c}^{+} \mathrm{Gr} 1^{-}$(left) and $\mathrm{CD} 11 \mathrm{~b}^{+} \mathrm{Gr} 1^{-}$(right) cells producing IL-10, TGF $\beta$, and TNFa were measured by intracellular cytokine staining and flow cytometry. Lung digest preparations were incubated with PMA, ionomycin, and brefeldin A as described and surface stained for CD11b, CD11c, and Gr1. Following fixation they were subsequently stained for intracellular up-regulation of TNFa, TGF $\beta$, and IL-10. (E) Kinetics of PC clearance over time post infection, expressed as PC nuclei microscopically counted in lung digest samples. Mean \pm standard deviations are reported for groups of 4 mice per strain, and are representative of 3 experimental replicates. Statistically significant differences between treatment groups at each timepoint are denoted as follows: $*, P<0.05$ by one-way ANOVA and Bonferroni post test. Asterisk above bar represent difference compared to uninfected controls for each strain, and asterisk above connecting line represents difference between knockout and WT strains. 

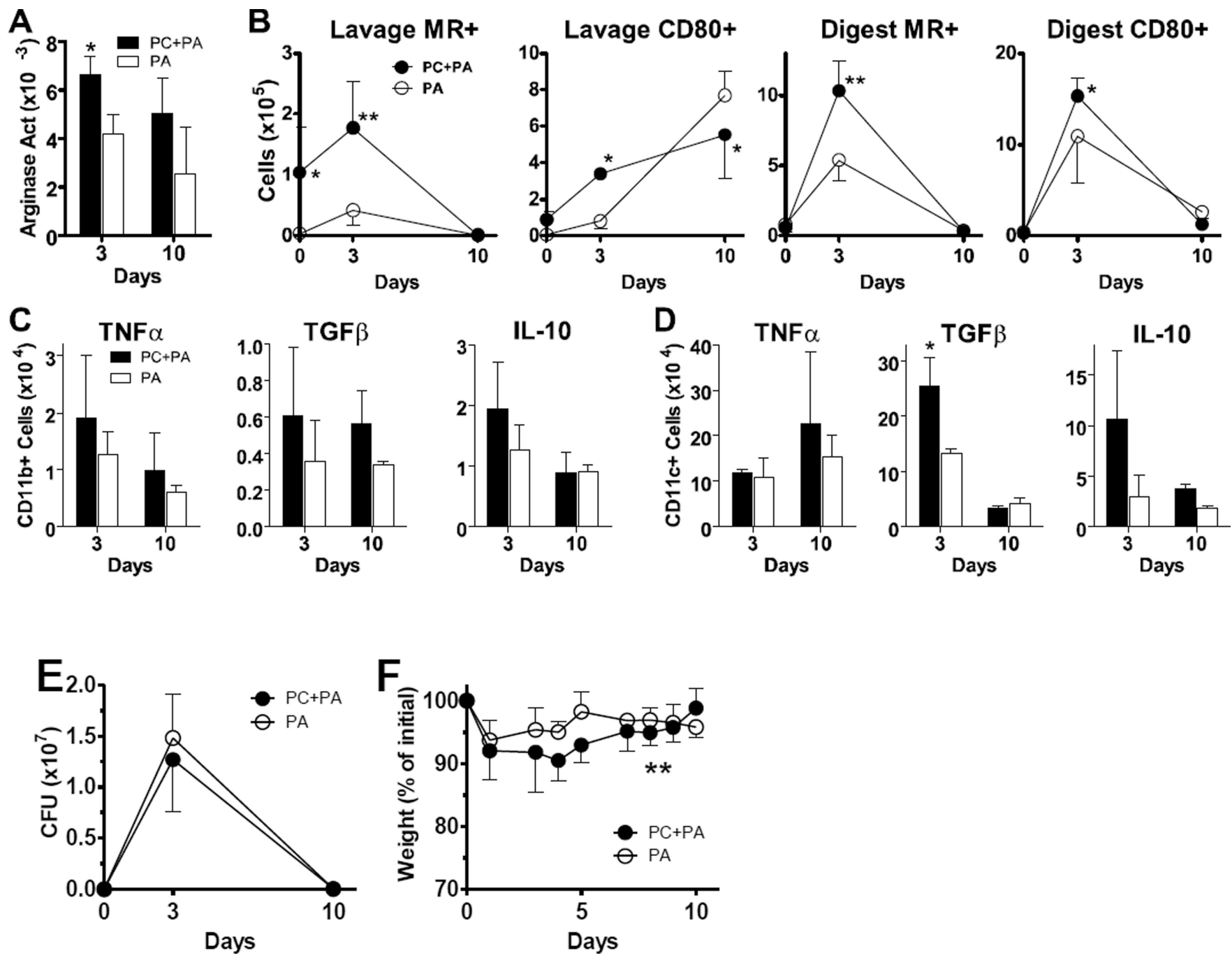

FIG 5.

Pneumocystis infection alters macrophage responses to subsequent Pseudomonas aeruginosa infection. Normal C57B1/6 mice were infected with $1 \times 10^{7}$ Pneumocystis (PC) nuclei (or sham infection) by intratrachael (i.t.) instillation and then challenged with $2 \times 10^{5} \mathrm{CFU} P$. aeruginosa (PA)-laden agarose beads it. 14 days later and euthanized at subsequent timepoints. Cells were isolated from the alveolar space via lung lavage, and whole lungs were digested to create single cell suspensions. (A) Arginase activity in lung digest was determined by measurement of the conversion of arginine into urea and standardized to total protein. (B) Cells isolated from lung lavage and lung digest samples were identified as $\mathrm{CD}_{11 \mathrm{~b}^{+}}$and stained for MR and CD80 protein expression and analyzed by flow cytometry. (C, D) The number of CD11 ${ }^{+} \mathrm{CD} 11 \mathrm{c}^{-}$(panel C) and CD11 b- CD11 $\mathrm{c}^{+}$(panel D) cells producing TNFa, TGF $\beta$, and IL-10 were measured by intracellular cytokine staining and flow cytometry. Lung digest preparations were incubated with PMA, ionomycin, and brefeldin $\mathrm{A}$ as described and surface stained for CD11b and CD11c. Following fixation they were stained for intracellular up-regulation of TNFa, TGF $\beta$, and IL-10. (E, F) $P$. aeruginosa clearance kinetics and mouse weights are shown over time for data pooled from all 
experimental replicates. Means \pm standard deviations (or SEM for P. aeruginosa CFU values) are reported for groups of 3-4 mice per timepoint per condition (or pooled as noted), and are representative of 2 experimental replicates. Statistically significant differences between treatment groups at each timepoint are denoted as follows: *, $P<0.05$; **, $P<0.01$ by two-way ANOVA and Bonferroni post test. 